\title{
KEBERAGAMAN BUDAYA MASYARAKAT INDONESIA
}

\author{
Noraidarayanti \\ Email: 2010128220011@mhs.ulm.ac.id \\ Program Studi Pendidikan IPS Fakultas Keguruan dan Ilmu Pendidikan \\ Universitas Lambung Mangkurat \\ Banjarmasin
}

\begin{abstract}
Abstrak
Antropologi sangat erat kaitannya dengan ilmu sosial, sebab ilmu sosial membahas mengenai kemanusiaan sama hal nya seperti antropologi. Di dalam antropologi membahas mengenai keragaman kebudayaan manusia, dimana setiap manusia memiliki kebudayaan yang berbedabeda dalam hidup bermasyarakat. Khususnya di Indonesia banyak sekali perbedaan budaya antar masyarakat yang dimana perbedaan suku, perbedaan kepercayaan, perbedaan cara hidup, hingga perbedaan lainnya.
\end{abstract}

Kata kunci: Budaya masyarakat

\section{PENDAHULUAN}

Menurut pengertian umum antropologi adalah sebuah ilmu yang mempelajari tentang manusia, maksudnya adalah tidak hanya manusia saja antopologi juga membahas tentang kebudayaan manusia dan perbedaan antara individu dengan individu lainnya. Maka dari itu ilmu antropologi ini sangat erat kaitannya dengan ilmu pengetahuan sosial, sebab kedua ilmu tersebut membahas mengenai kehidupan masyarakat. Di dalam antropologi ada keberagaman budaya antar masyarakat, yang dimana antara satu kelompok masyarakat dengan kelompok masyarakat lainnya belum tentu memiliki budaya yang sama seperti budaya dalam mata pencaharian, agama, budaya dalam bermasyarakat, dan lain sebagainya.

Di Indonesia banyak sekali ditemukan keberagaman budaya yang masih menunjukkan unsur persamaan yang besar, dikarenakan suku yang berada di Indonesia berasal dari nenek moyang 
yang sama ataupun dari rumpun bangsa. Kekayaan budaya yang ada di Indonesia baik itu lokal ataupun budaya daerah yang tersebar di seluruh nusantara.

\section{METODE PENELITIAN}

Metode yang digunakan dalam penulisan artikel ini menggunakan metode kepustakaan dimana saya mengumpulkan artikel ilmiah, jurnal, tesis, skripsi, buku dan sumber ilmiah lainnya. Lalu menelaah isi dari berbagai sumber tersebut dan menuangkannya dalam sebuah karya tulis artikel ini.

\section{PENGERTIAN ANTROPOLOGI}

Antropologi berasal dari kata anthropos yang berarti manusia, dan logos yang berarti ilmu pengetahuan. Menurut pengertian secara umum, Antropologi merupakan ilmu yang mempelajari unsur, kebudayaan, yang ada di kehidupan manusia. Menurut Koentjaraningrat, Antropologi merupakan ilmu yang mempelajari manusia dengan mengamati warna, fisik, dan kebudayaan masyarakat. Menurut Profesor I Gede A.B. Wiranata, dalam buku Antropologi Budaya (2011), Antropologi adalah sebuah ilmu pengetahuan yang mempelajari manusia sebagai makhluk bermasyarakat.

Oleh sebab itu, Antropologi difokuskan pada sifat fisik, produksi, tradisi, dan nilai yang ada dalam pergaulan hidup suatu masyarakat yang berbeda. Antropologi berbeda dengan disiplin ilmu lain yang membahas tentang manusia, yang dimana antropologi berfokus pada kajian manusia dari sudut keanekawarnaannya, baik itu dari segi warna fisik, perilaku, maupun dari cara berpikirnya.

Antropologi terbagi menjadi dua bagian yaitu:

a. Antropologi fisik yang membahas mengenai manusia dari sudut beraneka ragam warna fisik hingga dapat disebut Antropo-biologi, antropologi fisik terbagi menjadi paleoantropologi dan antropologi ragawi.

b. Antropologi budaya yang dimana antropologi ini membahas mengenai manusia dari keberagaman perilaku dan cara berpikirnya, Antropologi budaya terbagi menjadi prehistori, etnolinguistik, dan ernologi. 
Ilmu antropologi menilai manusia dari berbagai aspek, yang mencakup aspek fisik, emosi, sosial, dan kebudayaan. Selain itu adapun beberapa konsep dasar antropologi yang mencakup: kebudayaan, evolusi, cultur area ataupun daerah budaya, enkulturasi, difusi, akulturasi, etnosentrisme, tradisi, ras dan etnik, stereotip, kekerabatan, magis, tabu, dan perkawinan.

Antopologi mempunyai tiga tujuan utama, yaitu: mendeskripsikan cara kehidupan masyarakat dari berbagai sudut pada setiap periode dan karakter manusia yang hidup pada kelompok tertentu, memahami manusia sebagai kelompok masyarakat, dan menemukan beberapa prinsip umum yang berkaitan dengan gaya hidup manusia dan asal dari gaya hidup tersebut.

Hubungan ilmu antropologi sendiri dengan beberapa disiplin ilmu sosial lainnya adalah keterkaitan pembahasan mengenai manusia sebagai makhluk yang bermasyarakat, yang dimana ilmu tersebut membahas mengenai pola, budaya, dan tingkah laku manusia dalam bermasyarakat antar individu dan antar masyarakat.

\section{KEBERAGAMAN BUDAYA}

Keberagaman masyarakat disebabkan oleh kondisi dalam masyarakat yang terdapat perbedaan dalam berbagai macam bidang. Yang dimana terdapat perbedaan suku bangsa, ras, agama, kepercayaan, ideologi berpolitik, sosial dan budaya, hingga ekonomi. Keragaman yang dimiliki itulah merupakan kekayaan dan keindahan di wilayah negara Indonesia.

Budaya merupakan kebiasaan di suatu daerah tertentu yang lahir secara alami, berkembang, dan menjadi kebiasaan yang sulit untuk dirubah. Budaya masyarakat yang berada di pedesaan dan tinggal di daerah pantai tentunya berbeda. Dimana budaya masyarakat pedesaan memiliki karakteristik yang tenang dan cenderung tertutup. Sedangkan budaya masyarakat yang tinggal di daerah pantai memiliki karakteristik keras dan lebih terbuka.

Kekayaan budaya di Indonesia dapat dijadikan laboratorium hidup antropologi oleh para antropolog, budaya yang bersifat tradisional dan masih dipertahankan. Nilai tradisional seharusnya digali dan dipergunkan agar memenuhi tujuan untuk mendukung dan membangun agar nilai tradisional tersebut tidak bertentangan dengan nilai modern. 
Adapun hal-hal yang dapat menyebabkan di dalam budaya lokal, yang menyebabkan perpecahan, perbedaan pemahaman, dan makna. Contohnya seperti seseorang dari suatu suku tertentu yang berkunjung ke rumah seseorang yang bersuku jawa, ketika disuguhi makan sayur (yang dalam bahasa jawa jangan), dan ia menawarkan sayur tersebut dengan sebutan jangan, maka seseorang yang berbeda suku tadi akan bingung.

Semakin berkembangnya teknologi kebudayaan tradisional kini diangkat dan diliput para media dan memperkenalkannya kepada generasi muda dan dikembangkan mereka. Selain itu kebudayaan tradisional sering dipergunakan oleh para pejabat dalam acara-acara besar dan penyambutan tamu asing. Semakin dikenalnya budaya lokal oleh beberapa masyarakat luas maka budaya tersebut semakin berkembang.

\section{SIMPULAN}

Antropologi merupakan sebuah ilmu yang mempelajari mengenai manusia, yang dimana di dalam antropologi membahas mengenai kebudayaan manusia dalam bermasyarakat. Di Indonesia sendiri banyak sekali perbedaan budaya dari berbagai macam suku sehingga Indonesia merupakan wadah dari penelitian para antropolog. Antropologi sendiri terbagi menjadi dua yaitu antropologi fisik yang dimana berfokus pada fisik manusia itu sendiri, dan antropologi budaya yang berfokus pada kebudayaan manusia dalam bermasyarakat. Hubungan ilmu antropologi dengan ilmu sosial adalah keduanya sama-sama membahas mengenai kehidupan manusia dalam bermasyarakat, yang mencakup pola hidup, budaya, dan tingkah laku manusia dalam bermasyarakat. 


\section{REFERENSI}

Abbas, E. W. (2013). Mewacanakan Pendidikan IPS. Mewacanakan Pendidikan IPS.

Abbas, E. W. (2015). Pendidikan IPS Berbasis Kearifan Lokal. Wahana Jaya Abadi.

Abbas, E. W. (2018). Penguatan Pendidikan IPS Di Tengah Isu-Isu Global.

Handy, M. R. N, Mutiani, M., Putra, M. A. H., Jumriani, J \& Rahman, A. M. CULTURAL ACCULTURATION OF CHINESE: ETNOGRAPHIC STUDY IN BANJARMASIN. Jurnal Socius, 10 (1), 66-75.

Iskandar, J. (2017). Etnobiologi dan keragaman budaya di Indonesia. Umbara, l(1).

Mutiani, M., Supriatna N., Abbas, E W., Rini, T. P. W., \& Subiyakto, B. (2021). Technological, Pendagogical, Content Knowledge (TPACK): A Discursions in Learning Innovation on Social Studies. The Innovation of Social Studies Journal, 2 (2),135-142.

Norhayati, N., Abbas, E. W., \& Putra, M. A. H. (2019). Social Interaction Pattern Jelai Riverbanks South Basirih. The Innovation of Social Studies Journal, 1(1), 12-20.

Putro, H. P. N., \& Jumriani, J. (2020). KEHIDUPAN SOSIAL DAN EKONOMI MASYARAKAT BANTARAN SUNGAI SEBAGAI SUMBER BELAJAR IPS.

Subiyakto, B., \& Abbas, E. W. (2020). Strategi Pembelajaran IPS: Konsep dan Aplikasi.

Sutardo, T. (2007). Antropologi: Mengungkap keragaman budaya. PT Grafindo Media Pratama. 